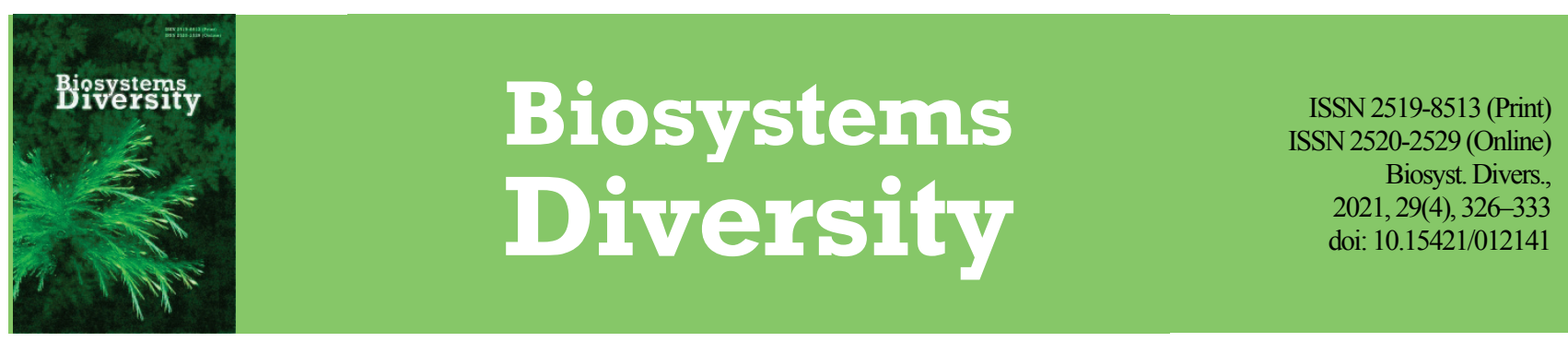

\title{
Seasonal variation in the diet and the morphometric parameters of the genus Pseudophoxinus sp. (Cyprinidae) in Eastern Algeria
}

\author{
S. Salhi*, R. Chaibi*, H. Badache**, M. Hamidouche***, R. Laouar**** \\ *University of Laghouat, Laghouat, Algeria \\ **University of Tunis El Manar, Rommana, Tunisia \\ ***Research Center in Industrial Technologies CRTI, Algiers, Algeria \\ ****Badji Mokhtar University, Annaba, Algeria
}

Article info

Received 01.10.2021

Received in revised form 25.10 .2021

Accepted 27.10.202

University of Laghouat, P.O. Box 37G, Laghouat, 03000, Algeria. Tel.: +213-697-040-522.

E-mail:s.salhi@lagh-univ.dz

University of Tunis El Manar-University Campus Farhat Hached Tunis, P.O. Box 94, Rommana, 1068, Tunisia. Tel.: +213-778-322-988.

E-mail:hocine89badache@hotmail.com

Research Center in Industrial Technologies CRTI, P.O. Box 64, Cheraga, Algiers, 16014, Algeria Tel.: +213-676-908-759.

E-mail:hamidouchemohamed@yahoo.fr

Badji Mokhtar University, P.O. Box 12, Annaba 23000 Algeria Tel $\cdot+213-795-534-308$

E-mail:rabahlaouan@yahoo.fr

\begin{abstract}
Salhi, S., Chaibi, R., Badache, H., Hamidouche, M., \& Laouar, R. (2021). Seasonal variation in the diet and the morphometric parameters of the genus Pseudophoxinus sp. (Cyprinidae) in Eastern Algeria. Biosystems Diversity, 29(4), 326-333. doi:10.15421/012141
\end{abstract}

The diet and the morphometric parameters of the Pseudophoxinus sp. (Cyprinidae) in the El Mellah ravine (M'sila, Algeria) were studied by determining body measurements and analyzing the contents of digestive tracts of 320 fish from December 2018 to November 2019. The obtained results show marked diversity within the fish species diets, which can be grouped into three main fractions: (i) a plant fraction; (ii) an animal fraction composed mainly of invertebrate prey; and (iii) fraction consisting of fish eggs (digested by males during the breeding season). The plant fraction was present in all the analyzed digestive tracts, mainly being composed of phytoplankton (algae), namely, Spirogyra sp., Melosira sp. and Navicula sp. with the total relative abundances of $38.7 \%, 34.4 \%$ and $4.1 \%$, respectively. On the other hand, the animal fraction was represented by the Chironomus sp., Austrosimulium sp., and Ecdyonurus sp. dipterans with a total relative abundance of 7.3\%,6.7\% and 5.9\%, respectively. Pseudophoxinus sp. eggs can also be considered as part of this fraction with the total relative abundance of $2.9 \%$. The age of the fish seems to have an influence on their feeding behaviour. The juveniles of Pseudophoxinus sp. in the study area had a purely phytophagous diet, while adults showed a phytophagous behaviour with an omnivorous tendency. The present study shows that not only the age of the fish but also the seasonal changes (climatic conditions and entry into the breeding season) may have a significant influence on the diet and morphometric parameters of Pseudophoxinus sp. in El Mellah ravine.

Keywords: fish nutrition; biometric parameters; seasonal variation; El Mellah ravine.

\section{Introduction}

It is important to know the morphometric parameters, diet and reproductive behaviours of species because these ae key aspects by which species are identified in their natural habitat. Thus, it important to preserve them from possible extinction, as they are among the important natural resources in their natural environment (Innal et al., 2019; Giannetto \& Innal, 2021).

In Algerian freshwater, Cyprinidae is a family where the genus $\mathrm{Pseu}$ dophoxinus sp. belongs. By abundance, Pseudophoxinus sp. of the Cyprinidae family is the second genus of endemic fish in Algeria after the Barbus genus and is either distributed or co-distributed with the latter in different places. The colour of Pseudophoxinus sp. species varies from light brown to light olive green on the back and upper sides, light yellow to creamy white on the lower sides and on the belly. Perea et al. (2010) stated that there are 14 distinct clades of Pseudophoxinus in the Mediterranean; while many works (Vaillant, 1904; Collares-Pereira, 1983; Dieuzeide \& Champagne, 1950) reported three species in North Africa: P. punicus, $P$. callensis and $P$. chaignoni. There are very few studies concerning freshwater fish in Algeria in general and the Pseudophoxinus specifically. Marfoua et al. (2017) focused their studies on the estimation of the metric characteristics for males and females of Pseudophoxinus sp., while Attir et al., (2017) aimed to study the phenomenon of parasitism in the gills, ectoparasites, and in digestive tracts. Other studies mainly focused on morphological parameters (Ould Rouis et al., 2020). Regarding the diet of fresh water fish in Algeria, the only study that could be found is the one by Mimeche et al. (2018), dealing with the seasonal patterns of the diet of the barbel Luciobarbus callensis in the K'sob reservoir (M'Sila, Algeria), whereas the diet, biological, phylogenetic and ecological data on Pseudophoxinus in general are surprisingly missing.

The study of dietary habits based on the analysis of digestive tract content (esophagus to the anal opening) is widely used in fish ecology as an important means to know the food relationship between the species in the aquatic communities (Arendt et al., 2001) and to understand the complex ecosystems (Lopez-Peralta \& Arcila, 2002). Knowing the diet of fish in a natural environment is one of the essential steps to understand both their ecology and biology. The knowledge of the species diet also helps explain the aspects of growth, reproduction and migration, especially for searching for food (Frank \& Solomon, 2016). These appear essential for habitat management and biodiversity conservation (Lowe-Mcconnell, 1982; Lebedeva et al., 2020), especially in such important, threatened and fragile ecosystems.

The objective of the present work was to study for the first time the diet composition of Pseudophoxinus sp. from El Mellah ravine (M'sila province, Algeria) by analyzing the digestive tract contents of 320 fishes throughout a year. The study can allow accurate determination of (1) the diet and reproductive behaviours, (2) the morphometric parameters of this fish, and (3) the effect of seasonal changes on its morphometric characteristics and feeding behaviour.

\section{Materials and methods}

El Mellah permanent ravine is located about $100 \mathrm{~km}$ from the capital of M'sila province and about $14 \mathrm{~km}$ north of Bensrour municipality. 
It drains the desert Atlas Mountains and infuses into the Shatt al-Hudna. Two native species of the cyprinid family (Pseudophoxinus and Barbus) live in this ravine (Marfoua et al., 2017). It is characterized by a semi-arid bioclimatic stage with moderate fluctuation and the water depth therein varies according to the percentage of seasonal rainfall and temperature. The catches of fish were made during the period of December 2018 to November 2019. Some environmental parameters are monitored periodically; the maximum temperature recorded being in August $\left(39.96^{\circ} \mathrm{C}\right)$, while the minimum temperature was recorded in December $\left(4.98{ }^{\circ} \mathrm{C}\right)$. The cumulative amount of rain was $391.5 \mathrm{~mm}^{3}$; the dissolved oxygen was $8 \mathrm{mg} / \mathrm{L}$, while the $\mathrm{pH}$ was 6.13 in August and 8.16 in December. The high temperature in summer (May to August) causes the water evaporation and consequently the decrease of the water volume in the ravine.

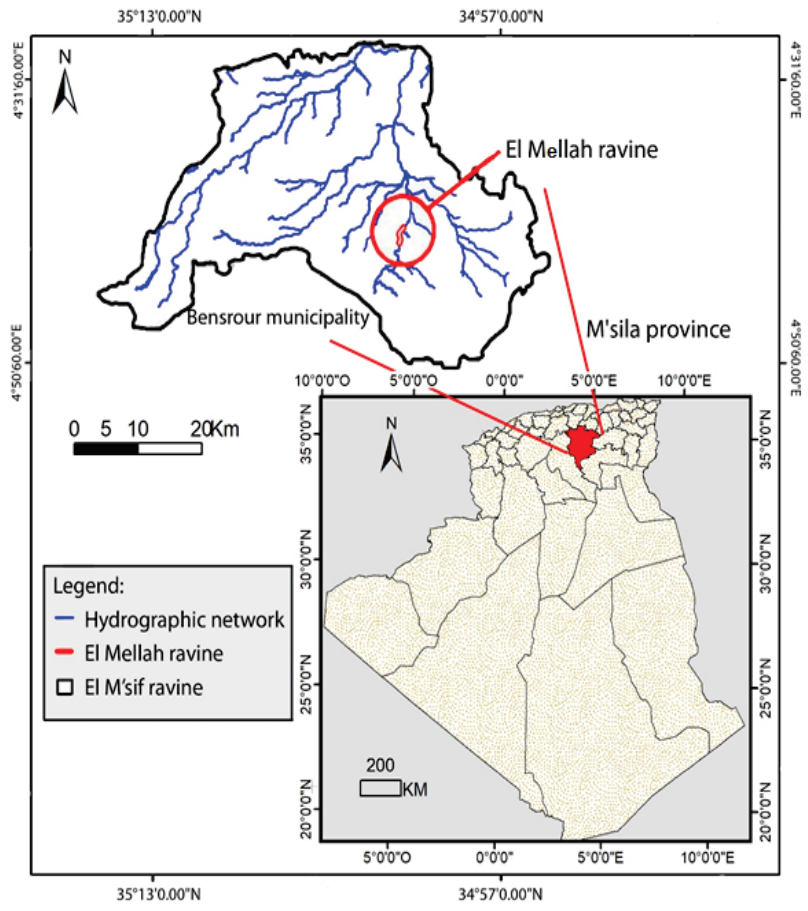

Fig. 1. Geographic Location of El Mellah ravine, Algeria

The sampling (catch of the fish) was done using a fishing net, with a mesh size of $10 \mathrm{~mm}$. It was carried out each month during the period from December 2018 to November 2019. The captured specimens (Fig. 2) were brought alive in a cooler to the laboratory, then immediately measured, weighed. Their gender and age were determined by observation under an optical microscope (4× magnification). The gonads were taken and weighed; however, the gender of some of them could not be determined due to their small sizes and poor appearance of the gonads.

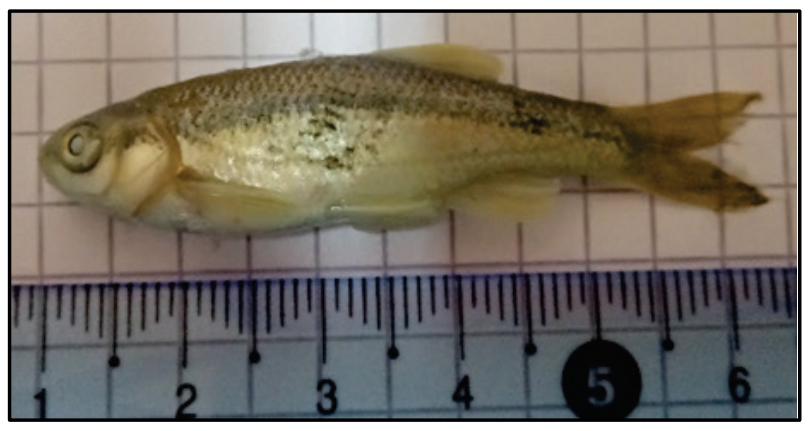

Fig. 2. The genus of Pseudophoxinus sp. of El Mellah ravine, Algeria

After the fish dissection, the contents of the digestive tract (from esophagus to the anal opening) were weighed, collected and preserved in vials containing $4 \%$ formalin solution, labeled and placed in fridge (at $-4{ }^{\circ} \mathrm{C}$ ). The digestive contents were observed using a laboratory binocular magnifying glass (Bresser Science, ETD-201 brand) and with an optical microscope (Optika B-383 brand). The observed prey were identified and clas- sified according to their nature (animal or plant). The genus of the insects and phytoplankton items were identified using the identification keys established by Craig (2019), Delaunay (2020), Diomande et al. (2000), Marquié et al. (2018). In the analysis of the morphometric parameters, several variables were taken into consideration, namely: the total length (L) and the standard length (l) of the fish in $\mathrm{cm}$, the total mass (M), the eviscerated mass $(\mathrm{m})$ and the liver weight ( $\mathrm{r}$ ) in grams. Also, we observed presence or absence of adiposity together with the gender of the fish, namely, male, female or indefinite. The length parameters were measured using a Vernier with the precision of $0.01 \mathrm{~mm}$, while, the each specimen and its liver were weighed using a G \& G Electronic precision balance with the accuracy of $0.0001 \mathrm{~g}$.

Depending on the obtained prey categories, various indexes were used for the quantitative and qualitative analyses of the diet. The calculated indices were those described by Hynes (1950) for determining the diet and the feeding activity of digestive tracts contents. It should be mentioned that these indexes were also used by several other researchers; such as, Mimeche et al. (2018), Benabid (1990), Cherghou et al. (2002) and Kraiem (1980). The used indexes were:

- the Vacuity coefficient (V, \%): is the ratio of the number of empty digestive tracts $(\mathrm{E})$ divided by the total number of the examined digestive tracts $(\mathrm{X})$;

- the Relative abundance $(\mathrm{R}, \%)$ : is the ratio of the total number of a prey category and $(\mathrm{N})$ divided by the total number of all prey categories $(\mathrm{P})$;

- the Coefficient of occurrence $(\mathrm{C}, \%)$ : is the ratio of the total number of fish with digestive tracts containing a given prey type (D) divided by the number of all-examined digestive tracts $(\mathrm{F})$;

- the Hepatosomatic index (H, (Lahaye, 1980)): is the ratio of the liver mass ( $\mathrm{r}$ ) in $\mathrm{g}$, divided by the mass of the eviscerated fish (m) in $\mathrm{g}$;

- the Gonadosomatic index (G, (Lahaye, 1980)): is the ratio of the gonad mass $(\mathrm{g})$ for males and females in $\mathrm{g}$, divided by the mass of the eviscerated fish (m) in $\mathrm{g}$.

The "IBM SPSS Statistics version 25" (Spss Inc. Chicago, Illinois, USA, 2017) software was used for all the statistical analyses. An unidirectional analysis of variance (One-way ANOVA test) was applied to analyze the evolution of the morphometric parameters of all fish with empty and full digestive tracts. The number of prey, in the case of full digestive tracts, was analyzed. The effect of the season changes on the all studied criteria was also taken as a parameter of study.

\section{Results}

As can be seen from Tables 1, 2 and 3, in the case of Pseudophoxinus sp., out of 320 examined digestive tracts, 145 were found empty, which represents a vacuity coefficient of $45.3 \%$. The highest percentage of empty digestive tracts was observed in summer, accounting for $23.7 \%$, while the lowest was observed in spring, equaling 5.3\%. By contrast, the analyzed full digestive tracts of Pseudophoxinus sp. contained two categories of food, which were the plant fraction and the animal fraction. The animal fraction was represented essentially by the "Insect prey" category, which was the most abundant and diverse (classified to three genera), whereas the fish component represents just a small percentage and is limited to a single species represented by the eggs of the studied fish itself. On the other hand, the relative abundance for insects was shown to be maximum in winter and especially for Chironomus sp., equaling $3.4 \%$. At the same time, the maximum relative abundance was found for plants (phytoplankton) of spirogyra in spring, accounting for $14.0 \%$. Referring to Table 2 , the occurrence coefficient of the overall prey of Pseudophoxinus sp. reveals some of the preferential encountered preysin the analyzed digestive tracts, which are phytoplankton (diatoms) represented by Melosira sp. and Spirogyra sp. with the same maximum rate of $25.1 \%$ in autumn. Concerning the insects, namely, Chironomus sp., Austrosimilium sp. and Ecdyonorus sp., the three insects exhibited the same maximum occurrence coefficient value with the rate of $16.6 \%$ observed in winter. It has to be noted that the fish in the summer did not eat insects, nor Navicula sp. phytoplankton, and were satisfied with only Melosira sp. and Spirogyra sp. Important proportions of sand were also discovered in the full digestive tract of Pseudophoxinus sp. with the maximum occurrence coefficient of $12.8 \%$ in winter. 
Table 1

Relative abundance (R, \%) of compounds ingested by Pseudophoxinus sp.

\begin{tabular}{lcccc}
\hline \multicolumn{1}{c}{ Items } & $\begin{array}{c}\mathrm{R}, \% \\
\text { winter } 2018\end{array}$ & $\begin{array}{c}\mathrm{R}, \% \\
\text { spring } 2019\end{array}$ & $\begin{array}{c}\mathrm{R}, \% \\
\text { summer 2019 }\end{array}$ & $\begin{array}{c}\mathrm{R}, \% \\
\text { autumn 2019 }\end{array}$ \\
\hline Chironomusp. & 3.4 & 1.7 & 0.0 & 2.2 \\
Austrosimulium sp. & 2.6 & 1.7 & 0.0 & 10.9 \\
Ecdyonurus sp. & 2.3 & 1.6 & 0.0 & 2.1 \\
Pseudophoxinus eggs & 0.0 & 2.9 & 0.0 & 0.0 \\
Navicula sp. & 2.1 & 1.2 & 0.0 & 0.8 \\
Spirogyra sp. & 12.3 & 14 & 0.7 & 11.7 \\
Melosira sp. & 11.3 & 1.9 & 0.6 & 10.6 \\
\hline
\end{tabular}

Table 2

Occurrence coefficient (C, \%) of compounds

ingested by Pseudophoxinus sp.

\begin{tabular}{lcccc}
\hline \multicolumn{1}{c}{ Items } & $\begin{array}{c}\mathrm{C}, \% \\
\text { winter 2018 }\end{array}$ & $\begin{array}{c}\mathrm{C}, \% \\
\text { spring 2019 }\end{array}$ & $\begin{array}{c}\mathrm{C}, \% \\
\text { summer 2019 }\end{array}$ & $\begin{array}{c}\mathrm{C}, \% \\
\text { autumn 2019 }\end{array}$ \\
\hline Chironomis sp. & 16.6 & 10.3 & 0.0 & 10.9 \\
Austrosimulium sp. & 10.6 & 10.3 & 0.0 & 10.9 \\
Ecdyonurus sp. & 10.6 & 10.3 & 0.0 & 10.9 \\
Pseudophoxinus eggs & 0.0 & 2.9 & 0.0 & 0.0 \\
Navicula sp. & 23.4 & 22.3 & 0.0 & 14.9 \\
Spirogyra sp. & 24.6 & 24.0 & 18.3 & 25.1 \\
Melosira sp. & 24.6 & 24.0 & 18.3 & 25.1 \\
Sand & 12.8 & 10.0 & 12.5 & 12.2 \\
\hline
\end{tabular}

Table 3

Variation in seasonal vacuity coefficient (V, \%) for the Pseudophoximus sp.

\begin{tabular}{lr}
\hline \multicolumn{1}{c}{ Seasons } & $\mathrm{V}, \%$ \\
\hline Winter 2018 & 9.7 \\
Spring 2019 & 5.3 \\
Summer 2019 & 23.8 \\
Autumn 2019 & 6.6 \\
\hline
\end{tabular}

The boxplots for morphometric parameters, the hepatosomatic index $(\mathrm{H})$, the gonadosomatic index $(\mathrm{G})$, and all the nutrients of the fish with full digestive tracts are shown in Figure 3. The seasonal variation was observed to have maximum values in winter and spring, and minimum values in summer for total mass (M), eviscerate mass (m), total length (L), and standard length $(\mathrm{l})$. The $(\mathrm{H})$ index displayed its maximum value in summer and winter while its minimum values appeared in spring. The $(\mathrm{G})$ index for males and females peaked in spring and had minimum value in summer. On the other hand, the items ingested by the fish were seen in the largest maximum amount and highest diversity (number of prey items) in winter followed by autumn and spring, with the presence of ingested Pseudophoxinus sp. eggs exclusively in spring, while the minimum amounts and number of ingested prey items was noted in summer with total absence of insects. Regarding the fish with empty digestive tracts, the boxplots presented in Figure 4 also show an obvious seasonal changes in all the morphometric parameters ((M), (m), (L), (l)) with maximum and minimum values in summer and in autumn, respectively, while the $(\mathrm{H})$ index revealed its maximum value in summer and autumn and its minimum in spring. In contrast, the $(\mathrm{G})$ index for females exhibited its maximum and its minimum values in spring and summer, respectively. It is noteworthy that the seasonal variation of the $(\mathrm{G})$ index of males cannot be studied in this case, because just a single male was found in spring. The results are shown in Tables 4, 5 and 6.

Table 4 presents the seasonal variation of morphometric parameters for the fish with full digestive tracts. Two important points to note are the presence of adiposity in all the analyzed fish, and the fact that fish of undefined gender were the most numerous, then females, while males were the least numerous. Furthermore, the one-way ANOVA analysis (for 175 fish with full digestive tracts) confirms that the seasonal variation of morphometric parameters is highly significant $(\mathrm{P}<0.001)$. In contrast, the posthoc test (Tukey test) regroups the $(\mathrm{M})$ and $(\mathrm{m})$ morphometric parameters into three groups: (a) summer, (b) autumn, and (c) winter with spring, while (L) and (l) are classified in four groups: (a) summer, (b) autumn, (bc) spring and (c) winter. The post-hoc test of $\mathrm{H}$ index presents three groups: (a) spring, (b) summer, (ab) winter \& autumn. The $\mathrm{G}$ index for males shows three groups: (a) summer, (b) autumn (c) winter and spring, while the $\mathrm{G}$ index for females is divided into four groups: (a) summer, (b) autumn, (c) winter and (d) spring. Table 5 demonstrates the seasonal variation of the morphometric parameters for the fish with empty digestive tracts. Compared with the fish with full digestive tracts, we can note the absence of adiposity. However, the fish with undefined gender always remained the most numerous, followed by the females and then the males, occurring in the lowest numbers. The results of the One-way ANOVA test for 145 fishes in this case also showed that the seasonal variation of all morphometric parameters was highly significant $(\mathrm{P}<0.001)$. Nonetheless, the $\mathrm{H}$ and $\mathrm{G}$ indexes had relatively less significances of seasonal variations, accounting for $\mathrm{P}=0.051$ and $\mathrm{P}=0.004$, respectively. According to the results of the Tukey test, the morphometric parameters $(\mathrm{L}),(\mathrm{l}),(\mathrm{m})$ are divided into two groups: (a) winter, autumn and spring, and (b) summer. (M) split into four groups: (a) autumn, (ab) spring, (bc) winter and (c) summer. The $\mathrm{H}$ index has four groups: (a) summer, (b) spring, (ab) winter and (c) autumn. The $G$ index for females shows two groups: (a) winter with autumn and spring, and (b) summer, while the G for index males cannot be performed by the Tukey tests because there was only one fish in spring, though there is a significant seasonal variation observed by oneway ANOVA test with $(\mathrm{P}=0.004)$.

Table 6 shows the seasonal variation of prey ingested by 175 fishes with full digestive tracts. The first observation was that the fish under two years old ate only phytoplankton, while the fish older than two years consumed insects in addition to phytoplankton in all seasons, except in summer when they ate only phytoplankton. On the other hand, the results of the one-way ANOVA test of 7,705 diverse items show that the seasonal variation either in number or type of nutrients ingested by the analyzed fish is very significant $(\mathrm{P}<0.001)$. Moreover, the nutrients ingested by the fish were grouped by post-hoc test as follows:

- concerning the animal fraction items (prey): Austrosimulium sp. and Ecdyonurus sp. represent two groups: (a) summer and (b) winter, autumn and spring, whereas Chironomus sp. shows four groups: (a) summer, (b) spring, (bc) autumn, and (c) winter;

- concerning the vegetable fraction items: Spirogyra and Melosira sp. are classified into two groups: (a) summer, (b) spring, winter and autumn, while Navicula sp. represents four groups: (a) summer, (ab) winter, (b) autumn, and (c) spring;

- concerning the Pseudophoxinus sp. fraction (eggs): the one-way ANOVA and Tukey tests cannot be carried out because fish males do not eat the eggs of females except during the reproduction phase in spring.

\section{Discussion}

As mentioned above, data on the morphometric features and the diet of the Pseudophoxinus sp., presented in this paper, are almost absent. Fiasson (1989) provided general information on the Cyprinidae family in Northern Algeria, which is the family that includes the Pseudophoxinus sp. Among the provided information, there is the total length of the fish, which is about $10.7 \mathrm{~cm}$. Unfortunately, this information cannot be compared with our results because the conditions of the study, such as the period during which the study was carried out, as well as the sex of the studied fishes and the exact location of the study were not mentioned. According to the literature, the only study of the Pseudophoxinus sp. so far which was carried out in the El Mellah Ravine, Algeria, is the one by Marfoua et al. (2017). However, the results of this study cannot be compared to our present work, because their observations were limited to one morphological parameter, which is the total length (L) of the fish, while our study took in consideration all the morphometric parameters, namely the indexes cited above. The fish diet, which is an important aspect in our study, was also not taken into consideration in their study. Even for total length, the results cannot be compared because their study of (L) was limited only to the period from December to May, whereas this study extended from December to November. In addition, our study dealt with the seasonal change in total length of the fish, while their study considered the average total length by sex (male and female). The only parameter that can be inferred by comparing the study of Marfoua et al. (2017) with our study is that the average total length recorded in their study for both males and females ( 7.2 and $7.4 \mathrm{~cm}$, respectively) is within the variation range of the total length in our study ( $4.49 \pm 0.40$ in summer to $6.05 \pm 1.42 \mathrm{~cm}$ in winter). 

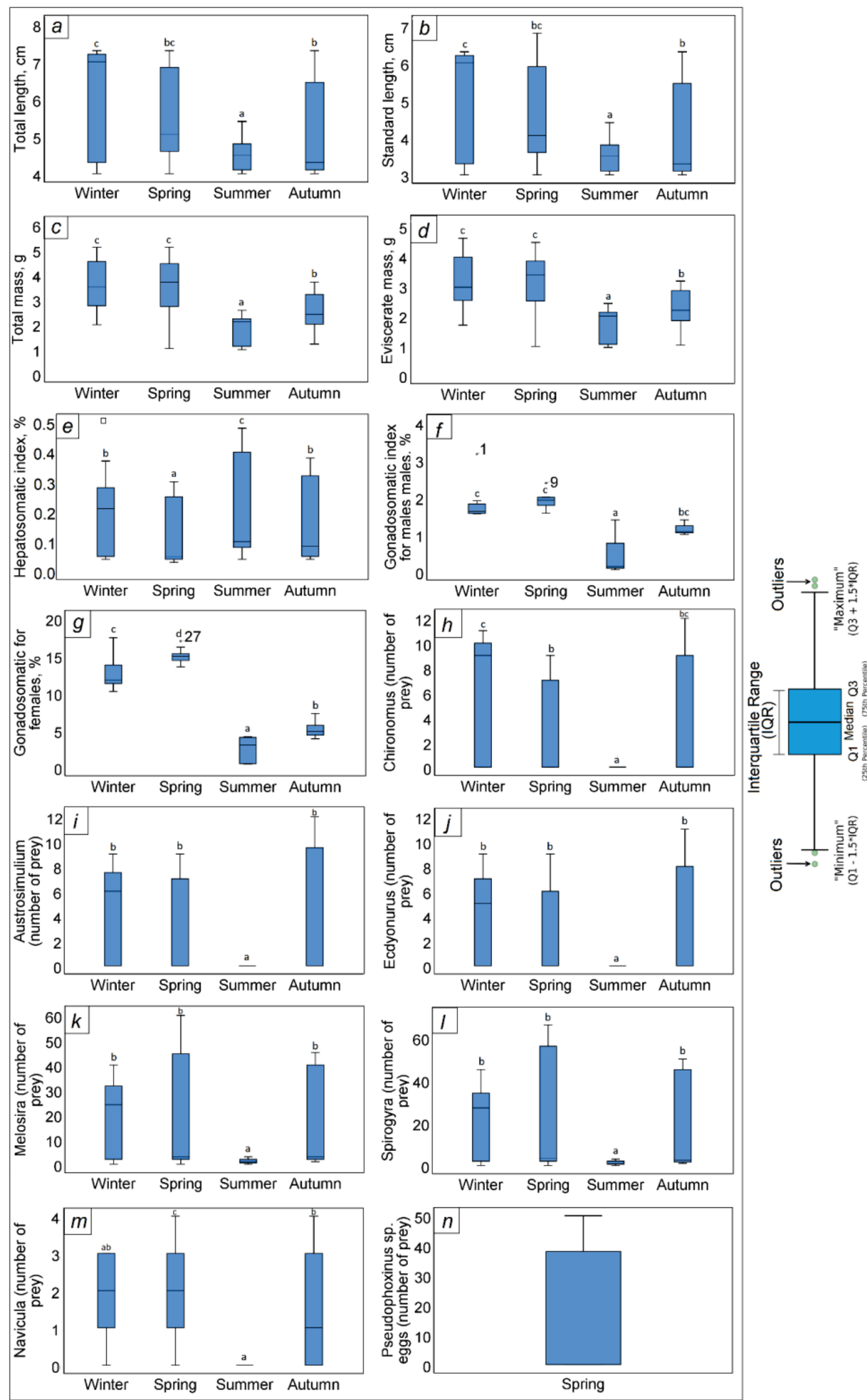

Fig. 3. Seasonal variation of the diet and the morphometric parameters of Pseudophoxinus sp. with full digestive tracts 


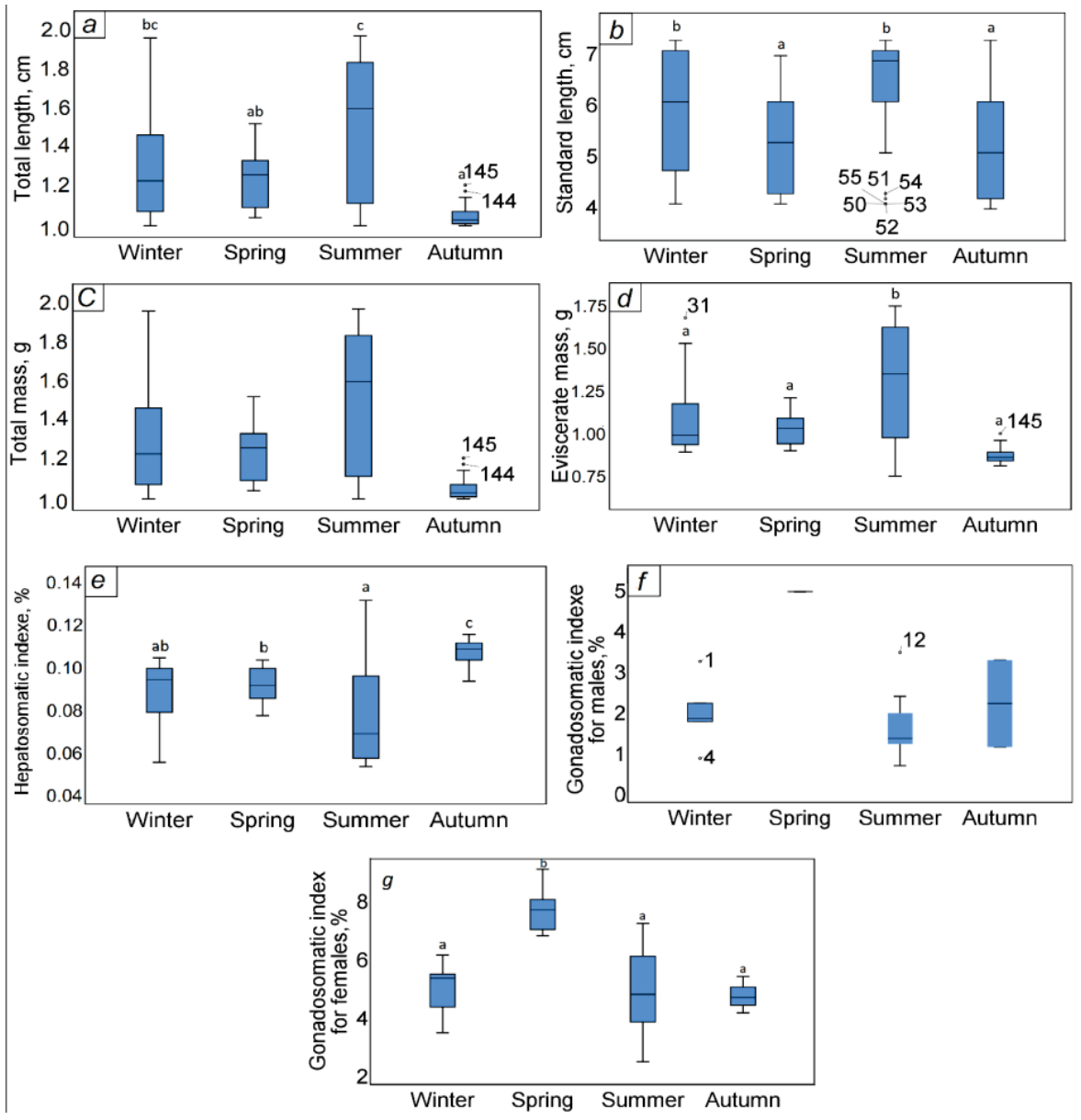

Fig. 4. Seasonal variation of the morphometric parameters of Pseudophoxinus sp. with empty digestive tracts

Table 4

Seasonal variation of the morphometric parameters of Pseudophoxinus sp. with full digestive tracts

\begin{tabular}{|c|c|c|c|c|c|c|c|c|c|c|c|c|c|}
\hline \multirow{2}{*}{ Variables } & \multirow{2}{*}{ Modalities } & \multicolumn{5}{|c|}{ Age (years) } & \multicolumn{3}{|c|}{ Gender } & \multicolumn{2}{|c|}{ Adiposity } & \multirow[b]{2}{*}{ No. } & \multirow[b]{2}{*}{$\mathrm{x} \pm \mathrm{SD}$} \\
\hline & & $0^{+}$ & $1^{+}$ & $2^{+}$ & $3^{+}$ & $4^{+}$ & indefinite & females & males & present & absent & & \\
\hline \multirow{4}{*}{$\begin{array}{c}\text { Total } \\
\text { mass (M), } \mathrm{g}\end{array}$} & winter & 7 & 9 & 10 & 9 & 9 & 16 & 21 & 7 & 26 & 18 & 44 & $3.575 \pm 0.157(\mathrm{c})$ \\
\hline & spring & 7 & 10 & 9 & 9 & 9 & 26 & 13 & 5 & 18 & 25 & 44 & $3.538 \pm 0.166(\mathrm{c})$ \\
\hline & summer & 7 & 9 & 9 & 9 & 9 & 35 & 5 & 3 & 18 & 25 & 43 & $1.800 \pm 0.088$ (a) \\
\hline & autumn & 7 & 9 & 9 & 10 & 9 & 25 & 16 & 3 & 19 & 25 & 44 & $2.530 \pm 0.120(\mathrm{~b})$ \\
\hline \multirow{4}{*}{$\begin{array}{l}\text { Eviscerate } \\
\text { mass }(\mathrm{m}), \mathrm{g}\end{array}$} & winter & 7 & 9 & 10 & 9 & 9 & 16 & 21 & 7 & 26 & 18 & 44 & $3.127 \pm 0.874(\mathrm{c})$ \\
\hline & spring & 7 & 10 & 9 & 9 & 9 & 26 & 13 & 5 & 18 & 25 & 44 & $3.075 \pm 0.849(\mathrm{c})$ \\
\hline & summer & 7 & 9 & 9 & 9 & 9 & 35 & 5 & 3 & 18 & 25 & 43 & $1.699 \pm 0.549$ (a) \\
\hline & autumn & 7 & 9 & 9 & 10 & 9 & 25 & 16 & 3 & 19 & 25 & 44 & $2.253 \pm 0.682(b)$ \\
\hline \multirow{4}{*}{$\begin{array}{c}\text { Total } \\
\text { length }(\mathrm{L}), \mathrm{cm}\end{array}$} & winter & 7 & 9 & 10 & 9 & 9 & 16 & 21 & 7 & 26 & 18 & 44 & $6.059 \pm 1.423(\mathrm{c})$ \\
\hline & spring & 7 & 10 & 9 & 9 & 9 & 26 & 13 & 5 & 18 & 25 & 44 & $5.581 \pm 0.174(\mathrm{bc})$ \\
\hline & summer & 7 & 9 & 9 & 9 & 9 & 35 & 5 & 3 & 18 & 25 & 43 & $4.490 \pm 0.400$ (a) \\
\hline & autumn & 7 & 9 & 9 & 10 & 9 & 25 & 16 & 3 & 19 & 25 & 44 & $5.184 \pm 1.249(\mathrm{~b})$ \\
\hline \multirow{4}{*}{$\begin{array}{c}\text { Standard } \\
\text { length (l), cm }\end{array}$} & winter & 7 & 9 & 10 & 9 & 9 & 16 & 21 & 7 & 26 & 18 & 44 & $5.059 \pm 1.423(\mathrm{c})$ \\
\hline & spring & 7 & 10 & 9 & 9 & 9 & 26 & 13 & 5 & 18 & 25 & 44 & $4.604 \pm 1.188(\mathrm{bc})$ \\
\hline & summer & 7 & 9 & 9 & 9 & 9 & 35 & 5 & 3 & 18 & 25 & 43 & $3.490 \pm 0.400$ (a) \\
\hline & autumn & 7 & 9 & 9 & 10 & 9 & 25 & 16 & 3 & 19 & 25 & 44 & $4.184 \pm 1.249(\mathrm{~b})$ \\
\hline \multirow{4}{*}{$\begin{array}{c}\text { Gonadosomatic } \\
\text { index }(\%) \\
\left(\mathrm{G}_{\text {males }}\right)\end{array}$} & winter & 0 & 0 & 3 & 1 & 4 & 0 & 0 & 7 & 7 & 0 & 7 & $1.872 \pm 0.581(\mathrm{c})$ \\
\hline & spring & 0 & 0 & 0 & 3 & 2 & 0 & 0 & 5 & 5 & 0 & 5 & $1.930 \pm 0.299(\mathrm{c})$ \\
\hline & summer & 0 & 0 & 0 & 3 & 0 & 0 & 0 & 3 & 3 & 0 & 3 & $0.526 \pm 0.749$ (a) \\
\hline & autumn & 0 & 0 & 0 & 3 & 0 & 0 & 0 & 3 & 3 & 0 & 3 & $1.156 \pm 0.205(\mathrm{bc})$ \\
\hline \multirow{4}{*}{$\begin{array}{c}\text { Gonadosomatic } \\
\text { index }\left(\mathrm{G}_{\text {ffomles }}\right) \\
\%\end{array}$} & winter & 0 & 0 & 7 & 8 & 6 & 0 & 21 & 0 & 21 & 0 & 21 & $0.120 \pm 0.031$ (c) \\
\hline & spring & 0 & 0 & 0 & 6 & 7 & 0 & 13 & 0 & 13 & 0 & 13 & $0.149 \pm 0.009(\mathrm{~d})$ \\
\hline & summer & 0 & 0 & 0 & 2 & 3 & 0 & 5 & 0 & 5 & 0 & 5 & $0.024 \pm 0.018$ (a) \\
\hline & autumn & 0 & 0 & 0 & 7 & 9 & 0 & 16 & 0 & 16 & 0 & 16 & $0.046 \pm 0.013(\mathrm{~b})$ \\
\hline \multirow{4}{*}{$\begin{array}{l}\text { Hepatosomatic } \\
\text { index (H), } \%\end{array}$} & winter & 7 & 9 & 10 & 9 & 9 & 16 & 21 & 7 & 26 & 18 & 44 & $0.187 \pm 0.017(\mathrm{~b})$ \\
\hline & spring & 7 & 10 & 9 & 9 & 9 & 26 & 13 & 5 & 18 & 25 & 44 & $0.131 \pm 0.016$ (a) \\
\hline & summer & 7 & 9 & 9 & 9 & 9 & 35 & 5 & 3 & 18 & 25 & 43 & $0.212 \pm 0.026(\mathrm{c})$ \\
\hline & autumn & 7 & 9 & 9 & 10 & 9 & 25 & 16 & 3 & 19 & 25 & 44 & $0.171 \pm 0.020(\mathrm{~b})$ \\
\hline
\end{tabular}

Note: total number of fish with full digestive tracts is 175 ; $\mathrm{P}$-value of one-way ANOVA test: * $-\mathrm{P}<0.05$, ** $-\mathrm{P}<0.01$ and ${ }^{* * *}-\mathrm{P}<0.001$; $\mathrm{H}-$ hepatosomatic index; Ggonadosomatic index for males and females of Pseudophoxinus sp. 
Table 5

Seasonal variation of morphometric parameters of Pseudophoxinus sp. with empty digestive tracts

\begin{tabular}{|c|c|c|c|c|c|c|c|c|c|c|c|c|c|}
\hline \multirow{2}{*}{ Variables } & \multirow{2}{*}{ Modalities } & \multicolumn{5}{|c|}{ Age } & \multicolumn{3}{|c|}{ Gender } & \multicolumn{2}{|c|}{ Adiposity } & \multirow{2}{*}{ No. } & \multirow{2}{*}{$\mathrm{x} \pm \mathrm{SD}$} \\
\hline & & $0^{+}$ & $1^{+}$ & $2^{+}$ & $3^{+}$ & $4^{+}$ & Indefinite & Females & Males & Present & Absent & & \\
\hline & winter & 8 & 6 & 6 & 6 & 5 & 14 & 11 & 6 & 0 & 31 & 31 & $1.282 \pm 0.259$ (bc) \\
\hline Total & spring & 6 & 4 & 4 & 2 & 1 & 10 & 6 & 1 & 0 & 17 & 17 & $1.229 \pm 0.139(\mathrm{ab})$ \\
\hline \multirow{3}{*}{$\operatorname{mass}(\mathrm{M}), \mathrm{g}$} & summer & 7 & 9 & 20 & 16 & 24 & 39 & 21 & 16 & 0 & 76 & 76 & $1.456 \pm 0.354(\mathrm{c})$ \\
\hline & autumn & 7 & 8 & 2 & 2 & 2 & 16 & 3 & 2 & 0 & 21 & 21 & $1.053 \pm 0.059$ (a) \\
\hline & winter & 8 & 6 & 6 & 6 & 5 & 14 & 11 & 6 & 0 & 31 & 31 & $1.061 \pm 0.207$ (a) \\
\hline \multirow{3}{*}{$\begin{array}{l}\text { Eviscerate } \\
\text { mass }(m), \mathrm{g}\end{array}$} & spring & 6 & 4 & 4 & 2 & 1 & 10 & 6 & 1 & 0 & 17 & 17 & $1.005 \pm 0.091$ (a) \\
\hline & summer & 7 & 9 & 20 & 16 & 24 & 39 & 21 & 16 & 0 & 76 & 76 & $1.285 \pm 0.342(\mathrm{~b})$ \\
\hline & autumn & 7 & 8 & 2 & 2 & 2 & 16 & 3 & 2 & 0 & 21 & 21 & $0.852 \pm 0.057$ (a) \\
\hline \multirow{4}{*}{$\begin{array}{l}\text { Total } \\
\text { length (L), } \mathrm{cm}\end{array}$} & winter & 8 & 6 & 6 & 6 & 5 & 14 & 11 & 6 & 0 & 31 & 31 & $5.741 \pm 1.202(\mathrm{~b})$ \\
\hline & spring & 6 & 4 & 4 & 2 & 1 & 10 & 6 & 1 & 0 & 17 & 17 & $5.252 \pm 1.009$ (a) \\
\hline & summer & 7 & 9 & 20 & 16 & 24 & 39 & 21 & 16 & 0 & 76 & 76 & $6.313 \pm 0.944$ (b) \\
\hline & autumn & 7 & 8 & 2 & 2 & 2 & 16 & 3 & 2 & 0 & 21 & 21 & $5.138 \pm 1.049$ (a) \\
\hline \multirow{4}{*}{$\begin{array}{l}\text { Standard } \\
\text { length (l), } \mathrm{cm}\end{array}$} & winter & 8 & 6 & 6 & 6 & 5 & 14 & 11 & 6 & 0 & 31 & 31 & $4.645 \pm 01.444$ (a) \\
\hline & spring & 6 & 4 & 4 & 2 & 1 & 10 & 6 & 1 & 0 & 17 & 17 & $4.252 \pm 01.009$ (a) \\
\hline & summer & 7 & 9 & 20 & 16 & 24 & 39 & 21 & 16 & 0 & 76 & 76 & $5.313 \pm 0.944(\mathrm{~b})$ \\
\hline & autumn & 7 & 8 & 2 & 2 & 2 & 16 & 3 & 2 & 0 & 21 & 21 & $4.035 \pm 0.962$ (a) \\
\hline \multirow{4}{*}{$\begin{array}{l}\text { Gonadosomatic } \\
\text { Index }\left(\mathrm{G}_{\text {ffemles }}\right), \%\end{array}$} & winter & 0 & 0 & 5 & 1 & 5 & 0 & 11 & 0 & 0 & 11 & 11 & $0.487 \pm 0.008$ (a) \\
\hline & spring & 0 & 0 & 3 & 2 & 1 & 0 & 6 & 0 & 0 & 6 & 6 & $0.076 \pm 0.008$ (b) \\
\hline & summer & 0 & 0 & 6 & 3 & 7 & 0 & 17 & 0 & 0 & 17 & 17 & $0.048 \pm 0.015$ (a) \\
\hline & autumn & 0 & 0 & 1 & 0 & 2 & 0 & 3 & 0 & 0 & 3 & 3 & $0.046 \pm 0.006$ (a) \\
\hline \multirow{3}{*}{$\begin{array}{l}\text { Gonadosomatic } \\
\text { index }\left(\mathrm{G}_{\text {males }}\right), \%\end{array}$} & winter & 0 & 0 & 1 & 3 & 2 & 0 & 0 & 6 & 0 & 6 & 6 & $0.019 \pm 0.008$ \\
\hline & summer & 0 & 0 & 5 & 3 & 8 & 0 & 0 & 16 & 0 & 16 & 16 & $0.015 \pm 0.007$ \\
\hline & autumn & 0 & 0 & 0 & 2 & 0 & 0 & 0 & 2 & 0 & 2 & 2 & $0.021 \pm 0.015$ \\
\hline \multirow{4}{*}{$\begin{array}{l}\text { Hepatosomatic } \\
\text { index }(\mathrm{H}), \%\end{array}$} & winter & 8 & 6 & 6 & 6 & 5 & 14 & 11 & 6 & 0 & 31 & 31 & $0.087 \pm 0.014(\mathrm{ab})$ \\
\hline & spring & 6 & 4 & 4 & 2 & 1 & 10 & 6 & 1 & 0 & 17 & 17 & $0.090 \pm 0.007$ (b) \\
\hline & summer & 7 & 9 & 20 & 16 & 24 & 39 & 21 & 16 & 0 & 76 & 76 & $0.075 \pm 0.021$ (a) \\
\hline & autumn & 7 & 8 & 2 & 2 & 2 & 16 & 3 & 2 & 0 & 21 & 21 & $0.105 \pm 0.005(\mathrm{c})$ \\
\hline
\end{tabular}

Note: total number of fish with empty digestive tracts is 145 ; P-value of one-way ANOVA test: ${ }_{-}-\mathrm{P}<0.05$, ${ }^{* *}-\mathrm{P}<0.01$ and ${ }^{* * *}-\mathrm{P}<0.001$; $\mathrm{H}-$ hepatosomatic index; $\mathrm{G}-$ gonadosomatic index for males and females of Pseudophoxinus sp.

Table 6

Seasonal variations of the items present in the analyzed digestive tracts of Pseudophoxinus sp. with full digestive tracts

\begin{tabular}{|c|c|c|c|c|c|c|c|c|c|c|c|}
\hline \multirow{3}{*}{ Variables } & \multirow{3}{*}{ Modalities } & \multirow{3}{*}{ No. } & \multirow{2}{*}{\multicolumn{5}{|c|}{$\begin{array}{l}\text { Presence or Absence of preys(“+”"presence, “-“absence) } \\
\text { according to the age of fish (in years). }\end{array}$}} & \multicolumn{3}{|c|}{ Gender } & \multirow{3}{*}{$\mathrm{x} \pm \mathrm{SD}$} \\
\hline & & & & & & & & \multirow{2}{*}{ indefinite } & \multirow{2}{*}{ females } & \multirow{2}{*}{ males } & \\
\hline & & & $0^{+}$years & $1^{+}$years & $2^{+}$years & $3^{+}$years & $4^{+}$years & & & & \\
\hline \multirow{4}{*}{ Chironomus sp. } & winter & 260 & - & - & + & + & + & 0 & 21 & 7 & $5.909 \pm 4.604(\mathrm{c})$ \\
\hline & spring & 129 & - & - & - & + & + & 0 & 13 & 5 & $2.931 \pm 3.611(\mathrm{~b})$ \\
\hline & summer & 0 & - & - & - & - & - & 0 & 0 & 0 & $0.000 \pm 0.000$ (a) \\
\hline & autumn & 172 & - & - & - & + & + & 0 & 16 & 3 & $3.909 \pm 4.649(\mathrm{bc})$ \\
\hline \multirow{4}{*}{ Austrosimulium sp. } & winter & 197 & - & - & + & + & + & 0 & 21 & 7 & $4.477 \pm 3.540(b)$ \\
\hline & spring & 132 & - & - & - & + & + & 0 & 13 & 5 & $3.000 \pm 3.741(b)$ \\
\hline & summer & 0 & - & - & - & - & - & 0 & 0 & 0 & $0.000 \pm 0.000$ (a) \\
\hline & autumn & 185 & - & - & - & + & + & 0 & 16 & 3 & $4.204 \pm 4.958(\mathrm{~b})$ \\
\hline \multirow{4}{*}{ Ecdyonurus sp. } & winter & 173 & - & - & + & + & + & 0 & 21 & 7 & $3.931 \pm 3.329$ (b) \\
\hline & spring & 122 & - & - & - & + & + & 0 & 13 & 5 & $2.772 \pm 3.415$ (b) \\
\hline & summer & 0 & - & - & - & - & - & 0 & 0 & 0 & $0.000 \pm 0.000$ (a) \\
\hline & autumn & 161 & - & - & - & + & + & 0 & 16 & 3 & $3.659 \pm 4.313(\mathrm{~b})$ \\
\hline \multirow{4}{*}{ Melosira sp. } & winter & 871 & + & + & + & + & + & 16 & 21 & 7 & $19.795 \pm 14.819(b)$ \\
\hline & spring & 915 & + & + & + & + & + & 25 & 13 & 5 & $20.795 \pm 23.422(\mathrm{~b})$ \\
\hline & summer & 48 & + & + & + & + & + & 18 & 3 & 2 & $1.116 \pm 0.878$ (a) \\
\hline & autumn & 820 & + & + & + & + & + & 25 & 16 & 3 & $18.636 \pm 19.430(\mathrm{~b})$ \\
\hline \multirow{4}{*}{ Spirogyra sp. } & winter & 947 & + & + & + & + & + & 16 & 21 & 7 & $21.522 \pm 16.089(\mathrm{~b})$ \\
\hline & spring & 1081 & + & + & + & + & + & 24 & 13 & 5 & $24.568 \pm 27.402(\mathrm{~b})$ \\
\hline & summer & 50 & + & + & + & + & + & 21 & 2 & 2 & $1.162 \pm 0.897$ (a) \\
\hline & autumn & 901 & + & + & + & + & + & 25 & 16 & 3 & $20.477 \pm 21.920(\mathrm{~b})$ \\
\hline \multirow{4}{*}{ Navicula sp. } & winter & 164 & + & + & + & + & + & 13 & 21 & 7 & $1.863 \pm 1.002(\mathrm{ab})$ \\
\hline & spring & 91 & + & + & + & + & + & 21 & 13 & 5 & $2.068 \pm 1.283(\mathrm{c})$ \\
\hline & summer & 0 & - & - & - & - & - & 0 & 0 & 0 & $0.000 \pm 0.000$ (a) \\
\hline & autumn & 62 & + & + & + & + & + & 7 & 16 & 3 & $1.409 \pm 1.435(\mathrm{~b})$ \\
\hline Pseudophoxinus sp. eggs & spring & 224 & - & - & - & + & + & 0 & 0 & 5 & $12.444 \pm 4.895$ \\
\hline
\end{tabular}

Note: number of prey (items) presents in the digestive tracts of the studied fish: No. $=7705$; P-value of one-way ANOVA test: ${ }^{*}-\mathrm{P}<0.05,{ }^{* *}-\mathrm{P}<0.01$ and ${ }^{* * *}-\mathrm{P}<0.001$.

The first feature taken into account with regard to the diet of the studied fish in this study is the vacuity coefficient. The latter varies considerably with the change of season. It was significantly lower in spring than in winter, which can be explained by the availability of macro invertebrates and micro invertebrates that the fish feed on in the ravine. In the summer, the increase in temperature leads to an increase in water temperature and decrease in the water level in the ravine. As a result, there is was decrease in the amount of fish prey and an increase in fish movement, which is very possible due to their search for food. This also lead to lower amount of prey in the digestive tract of the fish compared to other seasons, as well as to higher vacuity coefficient. Indeed, it was noticed that the highest vacuity coefficient was recorded during summer. 
The study of the seasonal variations of the food spectrum of Pseudophoxinus sp. shows that the nature and number of species ingested by the fish vary seasonally, with the predominance of phytoplankton (Melosira sp. and Spirogyra sp.) and zooplankton (Chironomus sp. and Ecdyonurus sp.) in autumn and winter. The latter is important for the reproduction period (Encina, 1999; Santos et al., 2013) which takes place during these two seasons, because of their high caloric content and their low mobility which facilitates their capture (Easton \& Orth, 1992). According to Puccinelli et al. (2019), the phytoplankton (diatoms) that is abundant in the digestive tracts of the studied fish is common in all aquatic ecosystems, and they represent the most essential and predominant components of benthic and planktonic assemblage. All this algal vegetation living in freshwater is a source of food for zooplankton, which in turn represents an important nutrient for fish living in lakes and rivers (Vivier \& Manguin, 1943). Moreover, the study of the seasonal evolution of phytoplankton populations by Fqih Berrada et al. (2000) showed that the evolution and growth of diatoms reach an algal peak in spring and summer as a result of favourable environmental conditions (climate, physico-chemistry of water and oxygen supply), in addition to the enrichment of the ravine in mineral elements caused by the presence of an area of eutrophication (agricultural area). This may well explain the dependence of fish on phytoplankton to a large extent in their diet and the increased relative abundance of phytoplankton in the digestive tract of the studied fish.

The different taxa items ingested by the fish could be classified into three groups: the first group consisting of algae, which were always present in the digestive tracts contents of fish with full digestive tracts during all seasons, the relative abundance of which was generally high; the second group comprising insects, the presence of which in the digestive tract contents was low and limited to a few seasons; the third group containing eggs, which were only present during the breeding season (spring), when the males eat a part of the eggs of females. This dietary diversity is an indication of the richness and abundance of potential prey species in the biotope of the studied fish (Adamek \& Obridlik, 1977; Lobon-Cervia \& De Diego, 1988). We have also noticed that because of the high number of small prey, the disadvantage of counting the amounts of prey favours small prey (zooplankton and phytoplankton) and underestimating larger preys (insects) (Bouhbouh, 2002). Likewise, we noticed that the presence of adiposity in the adult fish with full digestive tracts could be related directly to the presence of nutrients in their digestive tracts. This adiposity cannot be observed in the fish with empty digestive tracts. It should be noted that some elements ingested by fish such as sand were not included in the analysis, as they cannot be counted; their presence in the digestive tract of fish may be strongly related to the benthic behaviour of the fish (Lobon-Cervia \& De Diego, 1988) and to the way of food capture by collecting and scraping (Grandmottet, 1983). According to Kraiem (1996), the ingested sand has an important role in the fragmentation of the food ingested by fish.

It can be seen that the change of seasons significantly influences the variability of the diet (quantity and diversity) and the biometric parameters of the studied fish. Volkoff \& Rønnestad (2020) state that the most genera of fish are ectotherms, so the temperature strongly affects their physiology, metabolic rate and thus their energy balance, locomotor activity and feeding behaviour. It also influences the ability/desire of the fish to obtain food, and how they process food through digestion, how they absorb nutrients in the gastrointestinal tract and how they store the excess energy. In addition, Moullec et al. (2018) pointed out that temperature has a significant and major effect on biometrics (physiology), growth and the reproduction of the fish. Also, Doney et al. (2012) went on to say that temperature has an effect on freshwater ecosystems and food availability, so it can be stated here that the change in climate over the seasons would force fish to adapt their diets to the environmental conditions, and it influences the change in the morphometric parameters. In their recent study, Giannetto \& Innal (2021) showed that the decreasing water level and the climatic drought were found to be the threats that affect the fish communities the most.

In addition to the effect of seasonal change and sex of the fish, the diet of Pseudophoxinus sp. in the El Mellah ravine differed between juveniles and adults, the juveniles being phytophagous which consumed only diatoms (no animal prey in their digestive tracts), whereas adults had phyto- phagous diet with omnivorous tendency (presence of animal prey in their digestive tracts in addition to the phytoplankton prey).

In contrast, the presence of egg fraction in digestive tracts of all examined males in spring was probably due to the fact that the males of Pseudophoxinus sp. become cannibalistic during the breeding season, consuming the eggs of its females. This may be because they feel that the first set of eggs were not good enough and do not deserve to be kept as in the case of the blenny fish (Takegaki et al., 2011), or perhaps they selectively eat the eggs when they do not develop as quickly as others like in the case of the sand goby fish (Forsgren et al., 1996).

On the other hand, the difficulty of determining the sex of fish that were less than 2 years old was due to their small gonad size. A few exceptions were recorded in the spring, which represents the breeding season, when the swelling of their gonads during this season makes them clearly visible (Boët, 1980). This narrows the food bowl of the animal, and thus we see that there is congestion and not enough space for a large amount of food. Consequently, it was noticed that the lowest relative abundance of the items was recorded during spring. These results are consistent with those of Marfoua et al. (2017), who confirmed that the breeding season of the studied fish is exactly between February and March, which leads to the increase in gonad mass and consequently increase in the gonadosomatic index $(\mathrm{G})$ for both males and females in spring, on the other hand, the seasonal variation of the hepatosomatic index $(\mathrm{H})$ of the studied fish indicates that this fish stores the necessary reserves for the gonad maturation in its liver.

\section{Conclusion}

The present work presents for the first time the diet and morphometric parameters changes during one year of Pseudophoxinus sp. living in North Africa. According to the results, we can draw some important conclusions, which we summarized as follows.

The seasonal change showed its impact on the morphometric parameters of the fish in particular ( $\mathrm{L}$ and $\mathrm{M}$ ). This suggests that the studied fish is ectothermic and that its physiology and morphology are influenced by the climate change and the temperature variations during different seasons. Not only the morphology of the fish but also its feeding behaviour (amount and diversity) was strongly affected by the seasonal change, due to the change in the food availability, the diversity of prey species in the biotope of the fish and the variation in the climatic conditions and temperature. The entry into the breeding season also had an effect on the diet of the fish, as they prefer zooplankton during this period because of their high caloric content. These results showed the opportunism of Pseudophoxinus sp. and its great adaptability to environmental conditions (climatic and nutritional). In other words, this plasticity allowed the studied fish to live and colonize different areas with various environmental conditions.

The importance of the findings of this study is a much clearer view of the biological and ecological aspects of the genus Pseudophoxinus sp., endemic to Algeria. Such studies would help us to determine strategies for the preservation of this type of freshwater fishes that live in the arid regions of North Africa in general, and in Algeria in particular, where they are considered essential natural organisms of the ecosystem and of the heritage that should be preserved.

The authors wish to thank Abdelkrim Sibachir Professor of Biological Sciences at Batna 2 University, for his help and support in the realization of this study. The authors are also very grateful to the anonymous reviewer who carefully reviewed and helped improve quality of this manuscript.

\section{References}

Adamek, Z., \& Obridlik, P. (1977). Food of important cyprinid species in the Warmed Barb-Zone Oslava River. Folia Zoologica, 26, 177-182.

Arendt, M. D., Olney, J. E., \& Lucy, J. A. (2001). Stomach content analysis of cobia Rachycentron canadum from lower Chesapeake Bay. Fishery Bulletin, 99(4), 665-670.

Attir, B., Meddour, A., Sibachir, A., Ghazi, C., \& Ghouri, S., (2017). First report of Cichlidogyrus cubitus Dossou, 1982 (Dactylogyridea; Ancyrocephalidae) on 
Tilapia zillii in North West Africa. Journal of Applied Environmental and Biological Sciences, 7(3), 127-138.

Benabid, M. (1990). Bioécologie de deux espèces du barbeau (Barbus callensis (Gthr.) et Barbus labeobarbus fritschi (Val.) d'un cours d'eau du Haut-Atlas du Maroc. Thèse de Doctorat, Université de Marrakech, Morocco.

Boët, P. (1980). L'alimentation du poisson-chat (Ictalurus melas Raf.) dans le lac de Créteil. Annles de Limnologie, 16(3), 255-270.

Bouhbouh, S. (2002). Bio-ecology of Barbus callensis (Valenciennes 1842) and Babrus fritschi (Günther 1874) in Allal-el-Fassi Reservoir (Morocco). University of Sidi Mohamed, Maroc.

Cherghou, S., Khodjari, M., Yaakoubi, F., Benabid, M., \& Babdi, A., (2002). Contribution à l'étude du régime alimentaire du barbeau (Barbus barbus callensis Valenciennes, 1842) d'un cours d'eau du Moyen-Atlas (Maroc): Oued Boufekrane. Revue des Sciences de l'Eau, 15(1), 153-163.

Collares-Pereira, M. J. (1983). Estudo sistematico e citogenético dos pequenos ciprinideos ibéricos pertencentes aos géneros Chondrostoma Agassiz, 1835, Rutilus Rafinesque, 1820 e Anaecypris collares Pereira, 1983. Lisbon University, Lisbon.

Craig, D. A. (2019). Redescription of Austrosimulium bancrofti (Taylor) (Diptera: Simuliidae): Australia's second-worst problem black fly. Zootaxa, 4700(4), 535-556.

Delaunay, M. (2020). Comment faciliter l'identification de l'entomofaune?: Construction, évaluation et amélioration de clés d'identification numériques. Thèse de Doctorat, Muséum National d'Histoire Naturelle, Paris.

Dieuzeide, R., \& Champagne, R. (1950). L'Able de la Calle (Phoxinellus callensis Guichenot, 1850). Bulletin Statistique Aquic. Pêche Castiglione, 2, 171-184.

Diomande, D., Gourene, G., Sankare, Y., \& Zabi, S. G. (2000). Synopsis de la classification des larves et des nymphes de diptères chironomidae des ecosystèmes dulçaquicoles de l'Afrique de l'Ouest: Clés de détermination des sous-familles, des tribus et des genres. Archives Scientifiques, 17(1), 1-31.

Doney, S. C., Ruckelshaus, M., Emmett Duffy, J., Barry, J. P., Chan, F., English, C. A., Galindo, H. M., Grebmeier, J. M., Hollowed, A. B., Knowlton, N., Polovina, J., Rabalais, N. N., Sydeman, W. J., \& Talley, L. D. (2012). Climate change impacts on marine ecosystems. Annual Reviews of Marine Science $4(1), 11-37$.

Easton, R. S., \& Orth, D. J. (1992). Ontogenetic diet shifts of age-0 smallmouth bass (Micropterus dolomieu Lacepède) in the New River, West Virginia, USA Ecology of Freshwater Fish, 1(2), 86-98.

Encina, L. (1999). Ecología trófica del barbo (Barbus sclateri) en cuatro embalses de Sur de España. Limnetica, 17(1), 95-105.

Fiasson, J., (1989). Michel Le Berre. - Faune du Sahara. Volume 1. Poissons, amphibiens, reptiles. Illustrations de Jean Chevalier. Publ. Société Linn. Lyon 58 237-237.

Forsgren, E., Karlsson, A., \& Kvarnemo, C. (1996). Female sand gobies gain direct benefits by choosing males with eggs in their nests. Behavioral Ecology and Sociobiology, 39, 91-96.

Fqih Berrada, D., Berrada, R., Benzekri, A., \& Jabry, E. (2000). Évolution saisonnière des peuplements phytoplanctoniques dans le lac-réservoir El Kansera (Maroc), en relation avec certainsparamètres abiotiques et biotiques. Hydroécologie Appliquée, 12, 207-231.

Frank, P., \& Solomon, R. J. (2017). Comparison of haematological parameters between male and female catfish (Clarias gariepinus) grown in cow dung earthen pond. Direct Research Journal of Agriculture and Food Science, 5(1), 49-58.

Giannetto, D., \& Innal, D. (2021). Status of endemic freshwater fish fauna inhabiting major lakes of Turkey under the threats of climate change and anthropogenic disturbances: A review. Water, 13, 1534.

Grandmottet, J. P. (1983). Principales exigences de 30 téléostéens dulcicoles vis-à-vis de l'habitat aquatique. Annales Scientifiques de l'Université de Besançon. Biologie Animale, 4(4), 3-32.

Hynes, H. B. N. (1950). The food of fresh-water sticklebacks (Gasterosteus aculeatus and Pygosteus pungitius), with a review of methods used in studies of the food of fishes. Joumal of Animal Ecology, 19(1), 36-58.
Hyslop, E. J. (1980). Stomach contents analysis-a review of methods and their application. Journal of Fish Biology, 17, 411-429.

Innal, D., Çaglan, D. C., \& Özdemir, F. (2019). Species composition of fish community in Onaç Creek (Burdur-Turkey) and their length-weight relationships. Acta Biologica Turcica, 32, 135-142.

Kraiem, M. M. (1980). Structure et fonctionnement des écosystèmes du Haut-Rhône français. XXI Contribution à l'étude du régime alimentaire de Barbus barbus (L. 1758) (poissons, Cyprinidae). Bulletin Français de Pisciculture, 278, 1-10.

Kraiem, M. M. (1996). The diet of Barbus callensis (Cyprinidae) in Northern Tunisia. Cybium, 20(1), 75-85.

Lahaye, J. (1980). Les cycles sexuels chez les poissons marins. Oceanis, 6(7), 637654.

Lebedeva, D. I., Mendsaikhan, B., Yakovleva, G. A., \& Zaytsev, D. O. (2020) Parasites of Oreoleuciscus potanini (Cyprinidae) from lakes of Khar Us Nuur National Park (Mongolia). Nature Conservation Research, 5(Suppl.2), 57-71.

Lobon-Cervia, J., \& De Diego, A. (1988). Feeding of barbel (Barbus bocagei Steind) with relation to benthos composition. Archiv für Hydrobiologie, 114(1), 83-95.

Lopez-Peralta, R. H., \& Arcila, C. A. T. (2002). Diet composition of fish species from the southern continental shelf of Colombia. Naga, WorldFish Center Quarterly, 25(3/4), 23-29.

Marfoua, M., Souffi, I., Chaibi, R., \& Sibachir, A. (2017). Caractérisation biologique et écologique d'un poisson d'eau douce (genre Pseudophoxinus) dans l'Est Algérien. Journal Algérien des Régions Arides, 12(2), 84-92.

Marquié, J., Lefrançois, E., Boutry, S., Coste, M., \& Delmas, F. (2018). Guide d'identification: Les diatomées benthiques des cours d'eau de Nouvelle-Calédonie. Vol. 2. Observatoire de l'Environnement en Nouvelle-Caléd onie, 2, 58.

Mimeche, F., Zedam, A., Chafaa, S., Mimeche, H. \& Biche, M. (2018). Étude saisonnière du régime alimentaire du barbeau Luciobarbus callensis (Valencienne 1842) dans le réservoir de K'sob (M'Sila, Algérie). Revue des Sciences de l'Eau, 31, 163-171.

Moullec, F., Ben Rais LasraFm, F., Coll, M., Guilhaumon, F., Halouani, G., Hattab, T., Le Loc'H, F., \& Shin, Y. (2018). Sub-chapter 2.1.3. Climate change impacts on marine resources: From individual to ecosystem responses. In: Moatti, J. P., \& Thiébault, S. (Eds.). The Mediterranean Region under Climate Change: A Scientific Update, Synthèses. IRD Éditions, Marseille. Pp. 229-248.

Ould Rouis, S., Mansouri, H., Ould Rouis, A., Fergani, H., \& Arab, A. (2020). Length-weight relationship of a native fish in different freshwater systems in Algeria. Academia Journal of Scientific Research, 8(4), 168-174.

Pellegrin, J. (1920). Sur deux Cyprinidés nouveaux d'Algérie et Tunisie appartenan au genre Phoxinellus. Bulletin du Muséum National d'Histoire Naturelle, 26(5), 372-375.

Perea, S., Böhme, M., Zupančič, P., Freyhof, J., Šanda, R., Özuluğ, M., Abdoli, A., \& Doadrio, I. (2010). Phylogenetic relationships and biogeographical patterns in Circum-Mediterranean subfamily Leuciscinae (Teleostei, Cyprinidae) inferred from both mitochondrial and nuclear data. BMC Evolutionary Biology, 10, 265.

Puccinelli, C., Marcheggiani, S., \& Mancini, L. (2019). A patented rapid method for identification of Italian diatom species. International Joumal of Environmental Research and Public Health, 16, 3933.

Santos, J., Encina, L., Oliveira, J., \& Teixeira, A. (2013). Feeding ecology of the ruivaco Achondrostoma oligolepis, a Portuguese endemic cyprinid fish. Limnetica, 32, 27-38

Takegaki, T., Yoshimoto, Y., \& Matsumoto, Y. (2011). Filial cannibalism in the barred-chin blenny Rhabdoblennius ellipes: Males do not preferentially eat young eggs. Journal of Ethology, 29, 395-400.

Vaillant, M. L. (1904). Sur un Cyprinoide nouveau de Tunisie, le Leuciscus (Phoxinellus) chaignoni. ulletin du Muséum National d'Histoire Naturelle, 10, 188-190.

Vivier, P., \& Manguin, E. (1943). Les algues d'eau douce et leur interets en pisciculture. Bulletin Français de Pisciculture, 129, 137-155.

Volkoff, H., \& Rønnestad, I. (2020). Effects of temperature on feeding and digestive processes in fish. Temperature, 7(4), 307-320. 